\title{
Skeletal muscle tissue engineering: strategies for volumetric constructs
}

\author{
Giorgio Cittadella Vigodarzere and Sara Mantero* \\ Department of Chemistry, Materials and Chemical Engineering "Giulio Natta," Politecnico di Milano, Milano, Italy
}

\section{Edited by:}

Valentina Di Felice, University of

Palermo, Italy

Reviewed by:

Kunihiro Sakuma, Toyohashi

University of Technology, Japan

Jia Li, Harvard Medical School, USA

${ }^{*}$ Correspondence:

Sara Mantero, Department of

Chemistry, Materials and Chemical

Engineering "Giulio Natta,"

Politecnico di Milano, Piazza

Leonardo da Vinci 32, Milano

1-20133, Italy

e-mail: sara.mantero@polimi.it

\begin{abstract}
Skeletal muscle tissue is characterized by high metabolic requirements, defined structure and high regenerative potential. As such, it constitutes an appealing platform for tissue engineering to address volumetric defects, as proven by recent works in this field. Several issues common to all engineered constructs constrain the variety of tissues that can be realized in vitro, principal among them the lack of a vascular system and the absence of reliable cell sources; as it is, the only successful tissue engineering constructs are not characterized by active function, present limited cellular survival at implantation and possess low metabolic requirements. Recently, functionally competent constructs have been engineered, with vascular structures supporting their metabolic requirements. In addition to the use of biochemical cues, physical means, mechanical stimulation and the application of electric tension have proven effective in stimulating the differentiation of cells and the maturation of the constructs; while the use of co-cultures provided fine control of cellular developments through paracrine activity. This review will provide a brief analysis of some of the most promising improvements in the field, with particular attention to the techniques that could prove easily transferable to other branches of tissue engineering.
\end{abstract}

Keywords: skeletal muscle, tissue engineering, physical stimulation, mechanobiology, vascularization

\section{INTRODUCTION}

Skeletal muscle tissue represents the most abundant tissue type in the human body, amounting to $60 \%$ of the average weight. It is a metabolically active tissues requiring a constant flow of nutrients and metabolites, provided by an extensive capillary network forming an organized branching pattern throughout the fibers (Dennis and Kosnik, 2000; Liu et al., 2012).

Skeletal muscle tissue engineering (SMTE) aims to replicate the structure and function of skeletal muscle tissue in vitro and in vivo, to obtain valid models and functional constructs whose ultimate goal is the implantation as a therapeutic device (Ostrovidov et al., 2014). This discipline presents unique challenges compared to other tissue engineering strategies that have shown promise in clinical applications (Naito et al., 2003; Atala et al., 2006; Macchiarini et al., 2008; McAllister et al., 2009), in that small lesions and defects in skeletal muscle tissue seldom, if at all, require chirurgical intervention and transplantation; injuries heal spontaneously through an inflammation related mechanism (Ciciliot and Schiaffino, 2010; Turner and Badylak, 2012) involving resident stem cells, named satellite cells (SCs) (Pannérec et al., 2012).

Lesions so extensive that the function of the muscle is impaired are commonly designated volumetric muscle losses (VMLs) (Grogan et al., 2011); these lesions, mainly due to traumatic injury and chirurgical resection of tumors, are treated using free standing flaps as gold standard, a procedure that is inevitably associated with morbidity at the donor site and limited successful outcomes (Agostini et al., 2013). The use of flaps, rather than grafts, is a necessity because transplants of this kind cannot survive without an independent blood supply Similarly, clinically relevant SMTE constructs would require autonomous vascular networks to avoid central (Griffith et al., 2005; Bae et al., 2012; Shandalov et al., 2014).

However, in a clinical setting the goal of an SMTE device is the reestablishment of function rather than the original homeostasis of the tissue, there have been efforts to engineer constructs in which the contractile ability of the muscles is restored through functional fibrotic structures (Corona et al., 2013b); as long as there is a continuity in muscle architecture that allows the force transmission even a fibrotic structure formed from and acellular scaffold will ameliorate VML (Aärimaa et al., 2004).

Given the unique requirements in the treatment of the lesions in musculoskeletal tissues, SMTE constructs are designed to ameliorate large tissue defects and can only have limited clinical application without a vascular system to support the cellular component; similar considerations must be undertaken in the case of preclinical constructs, as large three dimensional structures have proven to replicate more closely the physiology of the original tissues (Rouwkema et al., 2011). It is necessary to mention that lesions occurring in craniofacial skeletal muscles (Garland and Pomerantz, 2012) must be set apart from the previous generalizations, as these tissues present a different cellular milieu compared to the muscles of the limbs and trunk (Kelly, 2010; Lemos et al., 2012); as such, it could be argued that different models should be produced to study these pathologies, though discipline may still prove of use for 
clinically applicable constructs due to the relatively restricted size of the lesions and the difficult application of flaps in this region.

\section{SKELETAL MUSCLE STRUCTURE}

The structure of skeletal muscle is inherently correlated to its function; this tissue is characterized by a highly ordered structure composed of parallel elements that can be summarily divided in myofibrils, muscle fibers and fascicles. A myofibril is the cytoplasmic molecular machinery capable of actuating muscle contraction through the relative movement of two interlocking macrostructures, the thin actin filaments and thick myosin filaments (Huxley and Hanson, 1954). Myofibrils are bundled within the massive cytoplasm of a multinucleated syncytium, the muscle cell or myofiber; motoneuron connections in the cell membrane (the sarcolemma) regulate the flow of calcium ions through the sarcoplasmic reticulum, necessary for the contraction of the myofibrils.

Myofibers constitute the parenchyma of skeletal muscle, and are bundled in a complex ECM structure which connects them to the muscle-tendon junction through three fibrous layers: the endomysium, surrounding individual myofibers, the perimysium, found over fascicles and the epimysium which cover the entire muscle.

The fine structure is particularly evident in decellularized muscles, where the bare extracellular matrix (ECM) forms structures not unlike bundles of flexible straws (Lieber and Fridén, 2000), which is the principal component of the muscle's anisotropic response to stress (Takaza et al., 2013). Blood vessels run along the fascicles in the perimysium and penetrate into the endomysium, forming capillaries that project around the myofibers; due to the elevated metabolic need of the skeletal muscle tissue, each myofiber is connected to a capillary (Figure 1). At the same time, the axons of motor neurons, which transmit the synaptic signal to the myofibers. Following the route traced by the blood vessels, motor neurons terminate into neuromuscular junctions in the proximity of sarcolemma-SR connections (triads); the association between the vascular and the nervous system is thought to start from the developmental phase of the organism

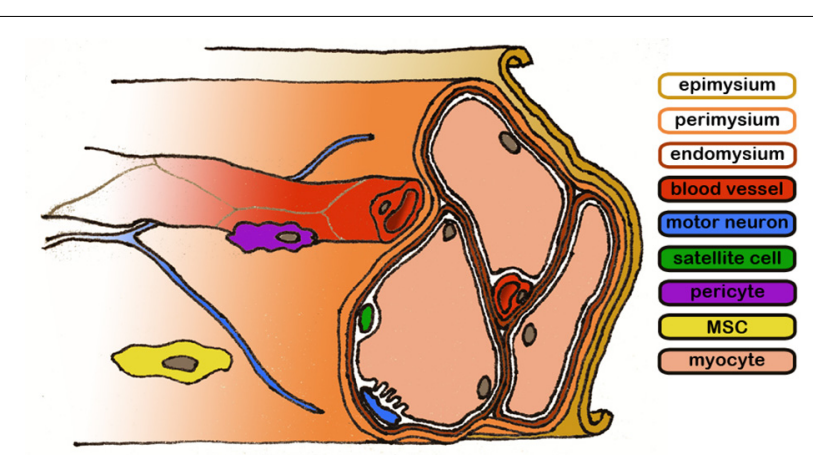

FIGURE 1 | Representative diagram of the skeletal muscle structure. Connective layers and cell populations of particular interest are evidenced. The biological components are not drawn to scale.
(Carmeliet and Tessier-Lavigne, 2005) and is conserved in regenerative processes involving a common mesenchymal progenitor cell able to generate musculoskeletal, nervous and vascular tissues (Tamaki et al., 2013).

The cellular machinery involved in the maintenance and regeneration of skeletal muscle tissue is the same responsible for. the delicate balance between hypertrophy and catabolism; these processes has been studied in detail (Joe et al., 2010; Ten Broek et al., 2010; Dellavalle et al., 2011; Turner and Badylak, 2012; Saclier et al., 2013), and three cellular populations have proven especially relevant to the regeneration process. SCs (Mauro, 1961), located between the basal lamina and the sarcolemma, are the tissue resident progenitor cells responsible for the maintenance and the continual production on myoblasts. Once activated, SCs will reveal heterogeneity in their population and will start dividing and producing muscle progenitor cells (MPCs) that eventually will become myoblasts and fuse to the existing myofibers (Boldrin et al., 2010); pathological conditions such as Duchenne muscular dystrophy (DMD) are known to deplete the reservoir of available SCs, leading to fibrosis and adipose tissue inclusion in muscular tissues.

SC pools can be replenished by muscular tissue pericytes (MPs), a population of cells found in close proximity to blood vessels and difficult to identify, as they bear no unique CD set or biochemical markers' (Dellavalle et al., 2011). These cells are capable of directing the behavior of endothelial cells (ECs), acting as guides during the formation of new blood vessels (Fuoco et al., 2014). Here, these cells have been shown to lose in part their ability to differentiate into myogenic lineage and to induce angiogenesis in nearby ECs as their host ages; nevertheless, the "myogenic/vasculogenic ability" appears to be restored after the cells are seeded on a polyethylene glycol-fibrinogen (PEG-F) surface. The mechanism underlying this behavior is yet to be elucidated, although a comparison with previous experiments by Discher et al. (2005) and Engler et al. (2006), might suggest a sensitivity to the mechanical stimuli of cellular environment.

Finally, fibro/adipogenic progenitors (FAPs) are a PDGFR $\alpha^{+}$ myogenic cell population, found in state of quiescence near blood vessels, which activates in case of injury to the muscle (Joe et al., 2010). FAP cells are known to promote the differentiation of MPCs but do not have any capability to generate muscle tissue on their own; on the contrary, they appear to be the main source of the fibrotic and adipose tissues found in pathological muscles (Uezumi et al., 2011). As such, these cells have been studied as a target for with microRNA (miRNA) treatments intended to reduce the symptoms of the DMD syndrome through the upregulation of the FAP cells myogenic programming, inducing a "compensatory regeneration" (Mozzetta et al., 2013; Saccone et al., 2014).

The interplay between these cell populations is fundamental for the continuous renewal of skeletal muscle tissue, required to compensate the damage occurring in day-to-day activities (Järvinen et al., 2013); however, pathological states also require the activation of the same cells in different processes that can result in the regeneration of the tissue or the formation of a fibrotic scar. 


\section{SKELETAL MUSCLE REPAIR PROCESS}

The regenerative process of muscle tissue is complex, and not yet understood in its entirety; different cell populations interact with each other and their environment to progress into outcomes which span from the reestablishment of function to fibrosis to pathological states of chronic inflammation (Koopman et al., 2014). A brief recapitulation of the phases of this process and the cellular populations involved will provide a background for the in vivo implantation of SMTE constructs, and will define some of the challenges involved in the development of in vitro devices. Skeletal muscle regeneration can be summarily divided into three overlapping phases: inflammation and activation of stem cells, differentiation and deposition of a provisional ECM and finally maturation of the tissues and remodeling of the ECM (Ciciliot and Schiaffino, 2010).

In the first phase (the peak is reached in $2 \mathrm{~h}$ ) of the regeneration process neutrophil granulocytes, innate immune response cells with antimicrobial activity, enter the lesion from the blood stream; their function is disputed but it has been proven that they possess antimicrobial activity, exert phagocytosis on tissue debris (Teixeira et al., 2003) and that they can stimulate vascularization through production of VEGF-A (Christoffersson et al., 2012); at the same time, however, this cell population releases cytotoxic compounds that can interfere with the regeneration process (Tidball and Villalta, 2010).

Another population of immune cells, the eosinophils, invade the tissue in this phase and activate FAP cells through the release of IL-4 (Heredia et al., 2013); after this initial stage the macrophages enter the lesion site: pro-inflammatory CD68+ CD163- macrophages (M1), which reach maximal concentration $24 \mathrm{~h}$ after the injury, followed by a switch in polarization leading to alternative activated, CD68- CD163+ macrophages (M2) with anti-inflammatory activity (Tidball and Villalta, 2010; Mantovani et al., 2013; Tidball et al., 2014). This activity bridges the inflammatory-proliferative phase with the following one, anti-inflammatory and differentiative; the shift is driven by the interaction between the macrophages and the SCs, which activate in response to the tissue injury and start an asymmetric replication cycle to produce myogenic progenitors (MP): simplistically, it can be said that during the initial phase SC division is stimulated by $\mathrm{M} 1$ macrophages via $\mathrm{TNF} \alpha$, then differentiation occurs through IL- 4 and IL-10 intervention by M2 cells. Whereas quiescent SC express a characteristic set of markers including Pax-7, M-Cadherin and CD 34, activated SC rapidly change this configuration as they proliferate; diminishing Pax -7 expression and producing basic helix-loop-helix (bHLH) transcription factors as they differentiate into committed MPs; these cells form multinucleated myotubes that express neonatal MyHC (Tidball et al., 2014). It is important to mention that only a fraction of the SC population possesses stemness and is capable of perpetuate itself and generate daughter cells of different phenotypes (Wang and Rudnicki, 2012).

At the same time, FAP cells rapidly multiply under IL-4 stimulation, enforcing an ambivalent role in the context of wound healing: while they provide MPs with growth factors necessary for their differentiation in myocytes, they are also the main origin of fibrosis in tissue repair and adipose tissue in pathological conditions (Uezumi et al., 2011; Heredia et al., 2013). In parallel, a population of connective tissue fibroblasts counterbalances FAPs' activity by dampening SC differentiation through the formation of a muscle connective tissue (MCT) and reciprocated paracrine signals (Murphy et al., 2011).

The final phase in muscle regeneration there is the resolution of the provisional ECM and the formation of a definitive structure that connects the stumps of the damaged fibers; in this process the basal lamina acts as a guide for the growth of the myofibers (Schmalbruch, 1976). The remodeling of the fibrotic tissue and the subsequent regeneration of the skeletal muscle, or lack thereof, is dependent on a variety of factors, including the vascularization and the innervation of the healing area. Generally, two positive outcomes can be envisioned as the resolution of the third phase: the regeneration of the muscle tissue, with the original architecture, or the formation of scar tissue and the separation of the muscle fibers (Ciciliot and Schiaffino, 2010; Turner and Badylak, 2012).

\section{VASCULARIZATION}

Vascular supply in the muscle is provided by a highly organized network of vessels, which are for the most part aligned with the direction of the muscle fibers. The organization of the structure is highly hierarchical an provides each myofiber with blood supply; the primary arteries run along the direction of the muscle fibers, and diverge inside the muscle through the epimysium via feed arteries; those are short branches that penetrate inside the muscle at an angle, or perpendicularly. Secondary arteriolar branches run again parallel to the muscle fibers, and then arterioles, through the perimysium, and finally connect to a microvascular unit composed of arterial and venous capillaries that follows the endomysium.

SMTE constructs, as well as any other tissue engineering construct which exceeds in any dimension the diffusion limit for oxygen and nutrients (Karande et al., 2004; Griffith et al., 2005; Radisic et al., 2006), require a specialized mean of delivery of such substances and removal of metabolic byproducts if they are to maintain the viability of seeded cells. Without these structures the constructs are likely to form necrotic cores (Radisic et al., 2004), compromising the regeneration process.

An arbitrary divide can be made between the techniques that see the formation of vascular structures in vitro and those that are implanted and develop vessels in vivo: in the first case various avenues have been explored to generate patterns within the volume of the engineered material so that the definitive shape of the network will be informed beforehand, whereas in the second case there is no specific structural conformation before implantation. This discrimination is necessary as current techniques are unable to produce mature blood vessel networks in vitro, meaning that a maturation process will always be present in the development of such constructs, if they are to be used as implants. Constructs intended as a vascularization models are subjected instead to different degrees of maturation in vitro, which determine the characteristic of their vascular structures, and as such will be discussed in the first group.

It can be argued that no engineered construct can be produced that will not incur into substantial remodeling upon 
implantation: even an hypothetical vascularized flap undistinguishable from the host's tissue would be colonized and altered by the surrounding capillaries, meaning that vascularization of implanted devices will always comprise an in vivo phase. According to this reasoning, the processes described here will be grouped according to whether they focus on the production of vascular structures within the constructs or the realization of constructs capable of allowing and increasing the penetration of the host vessels upon implantation.

\section{IN VITRO VASCULARIZATION}

Approaches for in vitro vascularization focus on the production and maturation of structured constructs before an eventual implantation; this is realized by producing an environment favorable to the formation of vascular compartments by vasculogenic cell populations, either by mechanical placement or through directed self-assembly (Table $\mathbf{1}$ ).

Constructs belonging to the first group are arguably the most numerous: they comprise those devices which implement structural and mechanical cues to direct the growth of vascular cells, most often ECs, endothelial progenitor cells (EPCs) and vascular smooth muscle cells (VMSCs). The methods used to produce the patterns include, most notably, sacrificial three-dimensional patterns (Miller et al., 2012; Hooper et al., 2014), direct deposition of cellular suspensions (Kolesky et al., 2014), self-assembly of polyelectrolyte solutions (Leong et al., 2013) or patterned cellular sheets (Muraoka et al., 2013), and usage of decellularized scaffolds, although the best known example refers to cardiac tissue (Ott et al., 2008; Koffler et al., 2011). In particular, the cell sheet techniques recently developed (Haraguchi et al., 2012; Nagamori et al., 2013; Sakaguchi et al., 2013; Sekine et al., 2013) resulted in the production of in vitro vascularized tissues using culture dishes coated with poly-N-isopropylacrylamide (PNIPAM) polymer derivatives that are able to modify the cellular adhesion by changing their hydrophilicity in a temperature range compatible with cell survival (Yamato et al., 2007). Interestingly, the interposition of a collagen sheet traversed with microchannels parallel to its surface through which was flowing medium was sufficient to generate the growth of vascular structures. These results indicate that ECs are able to respond to the mechanical cues generated by shear stress in adjacent vessels, even if these vessels are simply cavities in collagen; this is in accordance with findings in the field of vascular tissue engineering (Feaver et al., 2013) which describe the result of the mechanical stimulation on the phenotype of ECs. The complex effects resulting from cyclic mechanical stimuli are a valid tool in directing the behavior of vasculogenic cells and the generation of blood vessels (Kilarski et al., 2009; Boerckel et al., 2011), but the resulting vessels lack the order and pervasiveness of the natural vasculature; a better understanding of the cellular response to mechanical stress is therefore necessary to obtain mature, lifelike constructs.

On the other hand, devices that stimulate vascular growth in vitro without offering a predetermined pattern are not as common since scaffolds permitting unimpeded development of vascular structures are typically hydrogels, whose plastic qualities and wide range of possible biochemical and structural modifications make them more adapt for in vivo settings. Nonetheless, similar scaffold have been used to obtain networks either from preexistent structures (angiogenesis) (Chiu et al., 2012), or from isolated precursors (vasculogenesis) (Raghavan et al., 2010), demonstrating a better performance upon implantation compared to non-prevascularized constructs. This is also true for nonwoven polymeric scaffolds, where the random structure of the scaffold limits the control over the growth of vessels (Levenberg et al., 2005); these devices have also profited from the application of biologically-derived hydrogel coatings, which provided a more permissive to vascular growth (Lesman et al., 2011; Sadr et al., 2012). Finally, "spontaneous" in vitro vascularization is fundamental in engineering "myooids" (Dennis and Kosnik, 2000), self-aggregated constructs based on the mixed muscle cell population. These constructs are based on provisional ECM scaffolds synthesized by the fibroblast population present in the extract from minced muscle, and present a self-organizing vascular layout derived from the EC and the SMC population (Carosio et al., 2013).

Construct which do not present geometrically defined cues for the vascular development such as these rely instead on the vasculogenic properties of EPCs and their development in correlation with VSMCs, myoblasts and fibroblasts to obtain a viable network of vessels (Lesman et al., 2011; Alekseeva et al., 2014); however, these networks are rapidly restructured in vivo, and substituted with mature vessel which conform to the structure of the implant (Bae et al., 2012; Hanjaya-Putra et al., 2013). This means that these implants will undergo a vascularization process in vivo that will largely supersede the one completed in the in vitro phase; in the case of more mature vessels, the construct will connect to the existing vasculature in vivo through "wrapping and tapping" anastomoses (Cheng et al., 2011); after this passage, the construct will be replace with cells and matrix from the host's tissues, in an inflammation-like process requiring the chemotaxis of progenitors cells (Roh et al., 2010).

\section{IN VIVO VASCULARIZATION}

The development of blood vessels in vivo takes advantage of the host's regenerative capabilities, which can be regulated varying the cellular and chemical composition of the implanted device. The different phases that follows implantation recapitulate, optimally, those observed in regeneration, steering the wound healing process from a fibrotic/scarring outcome to a functional one (de Jonge et al., 2014).

While regenerative processes are necessary for the maturation of the former constructs into functional tissue, the immediate reaction to the engineered device is fundamental for the generation of a viable vessel network, since the in vivo vascularization requires a delicate balancing of the different phases of wound healing and regeneration following the implantation, so to achieve the necessary chemotaxis of progenitor cells and paracrine regulators without incurring in a state of prolonged inflammation (Gurtner et al., 2008).

There are two main tools with which to achieve this goal: the cellular component of the device and the structure and functionalization of the scaffold. The cellular components have been selected from autologous (Conconi et al., 2005), syngeneic, allogeneic (Corona et al., 2014) or xenogeneic (Kang et al., 2011) 
Table 1 | In vitro models of interest.

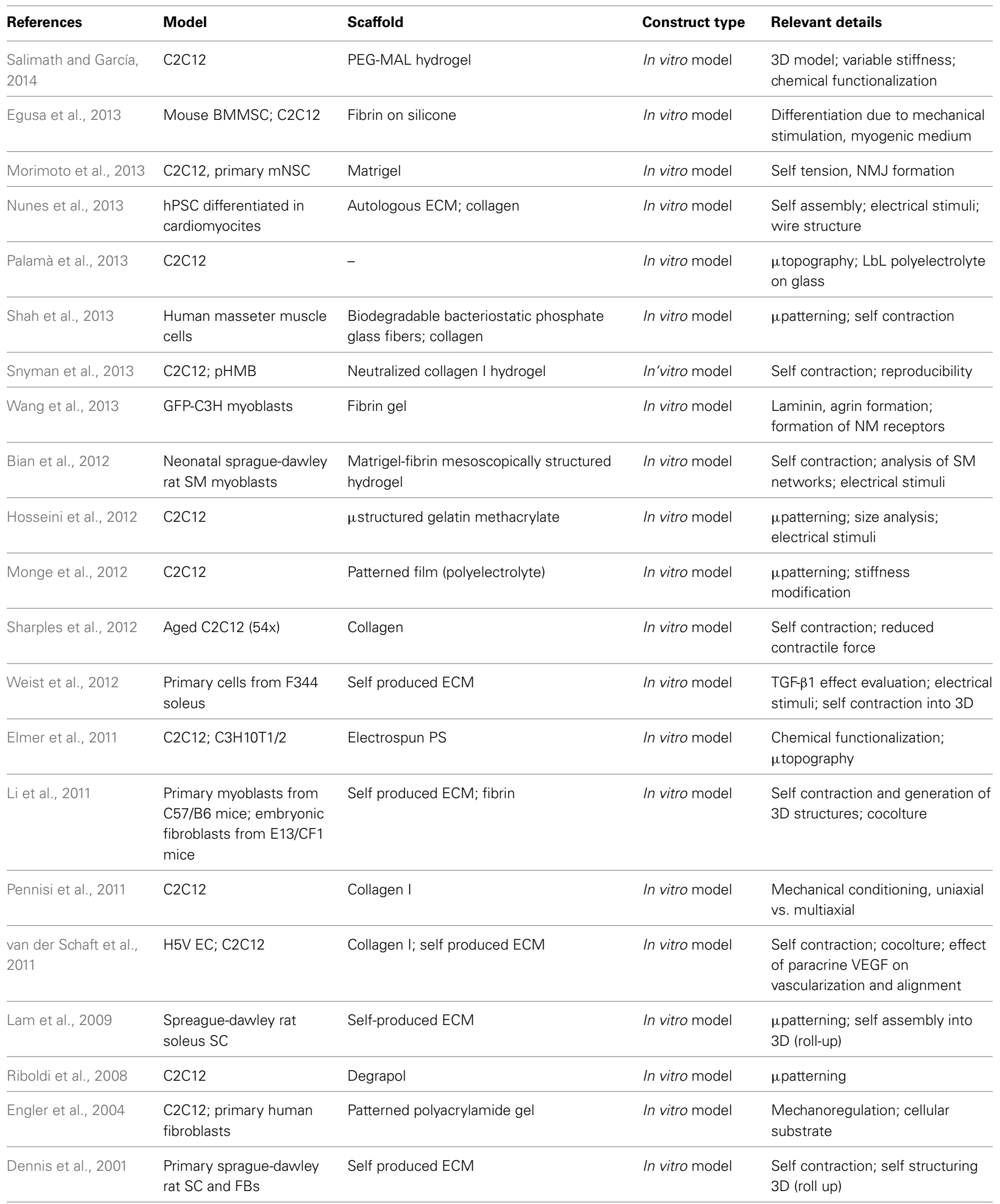

BMMSC: Bone Marrow Mesenchimal Stem Cell. EC, Endothelial Cell; FB, FibroBlast; GFP, Green Fluorescent Protein; hPSC, human Pluripotent Stem Cell; mNSC, mouse Neural Stem Cell; NM, NeuroMuscular; NMJ, NeuroMuscular Junction; PEG-MAL, PolyEthylene Glycol-MALeimide; pHMB, primary Human MyoBlast; SC, Satellite cells; SM, Skeletal Muscle. 
sources, and have been used directly or subsequently to genetic modification intended to increase their effectiveness through augmented expression of growth factors and cytokines (De Coppi et al., 2005). As for the scaffold, its structure can retain chemical signals and modify their local concentration, either geometrically or by surface modification which bind and/or release these factors at a controllable rate; similarly, scaffold derived from the decellularization of tissues are treated to minimize the immune reaction of a xenogeneic host (Badylak, 2014). Moreover, the rate of degradation, and the mechanical and topographical characteristics of the scaffold modify the behavior of the surrounding cells (Zhang et al., 2014), and therefore of the vascular compartment; uniform, randomized geometry, such as interconnected pore networks, facilitate the vascularization process, without imparting a definitive structure of the vascular compartment (Levenberg et al., 2005). However, since a functional design is proved to be advantageous in the integration of SMTE constructs (Koffler et al., 2011), and given that the process of vascularization is inextricably bound to the structural development of living tissues (Tirziu and Simons, 2009; Lesman et al., 2010), it is reasonable to assume that the presence of a defined architecture prior to implantation will inform the structure of the resulting implant, facilitating its integration in tissues characterized by a high degree of anisotropy such as skeletal muscle (Takaza et al., 2013).

\section{MECHANICAL AND PHYSICAL STIMULI}

Cells are sensitive to mechanical and physical changes in their environment, such as the bidimensional or tridimensional structure of the scaffold, its stiffness, or the presence of a voltage across the culture medium; recently, the effect induced by these parameters on cellular behavior have been studied in vitro, in the hope to obtain versatile tools for tissue engineering not subjected to the drawbacks suffered by biochemical signals, namely difficult application, limited availability and restrictive regulations.

The cellular mechanisms responsible for the translation of these signals into complex behavior are still being studied, notably in the engineering of tissues with load-bearing and dynamic functions (Guilak et al., 2014). Cells are able to feel and interact with their environment through specialized clusters of transmembrane proteins forming focal adhesions (FAs) (Eyckmans et al., 2011). These structures connect extracellular proteins and other surfaces viable to attachment to the cytoskeleton, the complex system of structural proteins that functions as an actuator of mechanical actions and as a sensor to the environment (Discher et al., 2005), translating its deformation into transcription factors headed for the nucleus; moreover, this structure forms a mechanical connection the nucleus and the Golgi Apparatus to the exterior of the cell (Wang et al., 2009), suggesting a close relationship between the shape of nucleus and the behavior of the cell (Nava et al., 2014).

In particular, the cytoskeletal architecture of the skeletal muscle is intrinsically related to its function and mediates the mechanical stimuli required in the maturation of tissue engineering constructs (Vandenburgh et al., 1988, 1991, 1999). In the original work of Vandenburgh et al. chicken myoblasts seeded on a collagen gel were exposed to stimuli meant to simulate processes observed in embryos, in accordance with the generally agreed principle that regeneration of tissue recapitulates embryonic development (Chargé and Rudnicki, 2004); the protocol, with some variations (Boonen et al., 2010), consists in an initial stretching corresponding to the elongation of the bone, followed by intermittent contractions similar to the impulses derived from postnatal stimuli (Riboldi et al., 2008). Skeletal muscle cells exposed to the correct stimuli show increased expression of differentiation markers compared to static cultures (Candiani et al., 2010), and progress into the formation of polynucleate syncytia; the reaction to cyclic strain, however, depends heavily on the amplitude and frequency of the stimuli: the same line of myoblasts have shown different reactions to alternate protocol and, interestingly, to alternate topographies. It has been shown (Ahmed et al., 2010) that myoblast cell lines tend to align to grooves in the substrate, but they respond to cyclic tension by forming striates stress fibers angled at $45^{\circ}$ with respect to the direction of the deformation; finally, on flat surfaces, cyclic mechanical stretching induces fiber angled ad $70^{\circ}$ to the stretching axis, attributed to the perpendicular contraction due to the Poisson's ratio of the material. Given the complex behavior exhibited by the cells in response to mechanical stimuli, a reliable protocol for cellular alignment would prove of great value in the engineering of tissues with specific geometric requirements ( $\mathrm{Li}$ et al., 2013b).

An interesting interpretation has been proposed recently Equation (1) (Livne et al., 2014), which considers the dissipation of cellular elastic energy as the principal reorientation factor The resulting model predicts the orientation angle of the cells $\theta$ based on a dimensionless parameter specific of the cell line and the ratio between principal strain and the Poisson ratio of the support:

$$
\bar{\theta}=\operatorname{arcos}\left(\sqrt{b+\frac{1-2 b}{r+1}}\right)=\arctan \left(\sqrt{\frac{r+b \cdot(1-r)}{1-b \cdot(1-r)}}\right)
$$

where $r$ is the negative inverse of the ratio between the principal strain and its perpendicular counterpart, and $\mathrm{b}$ is a dimensionless parameter that depends from the ratio between the cellular Young modulus along its main orientation axis $\left(\mathrm{E}_{\theta \theta}\right)$ and that along the perpendicular axis $\left(\mathrm{E}_{\rho \rho}\right)$. Although this model is capable of predicting the orientation angle well within a significant confidence interval in a bidimensional setting, it is yet to be tested with multiple cell lines or in a three dimensional environment, a setting that is known to influence cell behavior in a complex manner (Boonen et al., 2010). Nevertheless, it provides a relatively straightforward interpretative key to the disposition of cells in load bearing and dynamic tissues, provided of course that the parameter $b$ could be used in cells with high aspect ratio such as myocytes.

While the disposition of the cells in response to mechanical stimuli can be approximated to a purely physical process, growth, differentiation and function are far more complex behaviors; a viable avenue for this kind of research lies in the automated analysis of the cellular response to every possible combination of multiple factors. This technique can provide a unifying research framework and it can be used to rapidly individuate unexpected cellular responses to specific sets of stimuli. Similar approaches have been used to determine the reactions of undifferentiated cells to 2D topography (Unadkat et al., 2011), biomaterial composition (Mei et al., 2010), stiffness in 3d scaffolds (Sala et al., 2011) 
and a combination of 3D scaffolds and growth factors (Ranga et al., 2014). On a final note, it is worthwhile to mention that these combinatorial studies are also limited in that they expose the cell to repetitive stimuli that do not accurately replicate the environment: the ECM is characterized by a controlled randomness, which has proven to influence cell behavior in bidimensional studies (Dalby et al., 2006; Biggs et al., 2010); it can be argued then that these studies can only provide a framework for the identification of complex stimuli to be analyzed subsequently with more accurate techniques.

\section{CLINICAL APPLICATIONS_-PRESENT AND FUTURE}

As of now, SMTE constructs are either intended as in vitro skeletal muscle disease models (Gayraud-Morel et al., 2009; Vandenburgh, 2010; Kelc et al., 2013) (Table 1) or as in vivo preclinical research tools (Turner et al., 2012; Carosio et al., 2013; Mertens et al., 2014) (Table 2).

The only regenerative medicine devices to have reached clinical application are acellular compounds derived from animal ECM used in loco to improve the motility and strength of skeletal muscles subjected to traumatic injury (Mase et al., 2010; Sicari et al., 2014), or cell therapy strategies that are injected locally and systematically to improve syndromes stemming from genetic diseases (Tedesco et al., 2010; Tedesco and Cossu, 2012). While these therapies use tissue engineering techniques, they do not fall into the classic definition of TE constructs (Langer and Vacanti, 1993), since they lack either a cellular component or a scaffold and are not subjected to maturation in a bioreactor. Nonetheless, it is likely that future TE devices will refer to these forerunners as a model on which to improve, and that further early approaches in this field will implement methodologies that have proven most effective on their own in clinical trials.

\section{TOWARD A HUMAN HOST}

In the translation to the clinic, TE devices face a unique set of challenges due to their being artificial constructs made of synthetic and biologic material, the latter being of autologous, syngeneic or even xenogeneic origin (Mertens et al., 2014); setting aside the regulatory aspects of this progression, which have been recently described in details (Pashuck and Stevens, 2012; Fisher and Mauck, 2013; Martin et al., 2014) there are some aspects in the development of a preclinical engineered skeletal muscle device that are of particular relevance when considering clinical applications.

Most of the SMTE constructs that are currently being developed rely on small mammals as animal models to study their effects on muscle repair (Table 2 ); these models are reliable, easily available and provide comparable result between different laboratories, yet they also suffer from substantial limitations in the translation to the clinic (Boldrin et al., 2010; Seok et al., 2013; Bareja et al., 2014). In most cases, human cell lines and primary cells are used to develop constructs that are subsequently implanted in athymic models, lacking therefore the ability to mount an adaptive immune response; these models allow for the maturation of the implant in a living subject, under the reasoning that subsequent human trials would rely on autologous cells and scaffolds proven to be clinically compatible. However, the reaction to the human molecular apparatus found in the cellular compartment of the devices may differ from that originating from the host (Borisov, 1999). The predictive capability of these models in regard to cellular behavior under growth factor stimulation was put into question in a recent paper (Mujagic et al., 2013), where the authors suggested that the effects of different species' isoforms of the growth factor VEGF vary greatly depending on the recipient cells: this would explain the apparent inability of human VEGF to cause angiomas in mouse models, which could lead to an underestimation of the side effects of modified cells in autotransplantation cases. As a consequence, other studies which propose the use of genetically modified cells to improve the vascularization of regenerating muscles (Gianni-Barrera et al., 2013; Shevchenko et al., 2013) may have to compensate the effects observed in animals as to avoid the formation of irregular vasculature in human hosts; moreover, these uncertainties are also observed in clinical cases involving novel combinations of accepted materials and cellular populations, particularly undifferentiated staminal cells, which, if unregulated, could lead to ectopic tissue formation and neoplastic lesions (Amariglio et al., 2009; Thirabanjasak et al., 2010).

There are currently few ways to solve this problem, as the understanding of the interaction between host and implant is still largely incomplete, particularly in regard to the role of the immune system (Bohgaki et al., 2007); however, given the urgent need for reliable constructs capable of supplementing and replacing tissue transplants, alternative solutions to this problem could be found in therapies that do away entirely with the cellular component of the graft (Burdick et al., 2013), or in the development of cellular populations such as autologous induced pluripotent stem cells (iPSCs) (Takahashi and Yamanaka, 2006), which could solve the problems correlated with allotransplantation (Araki et al., 2013). Nevertheless, as these cells are capable of forming teratomas (Knoeplfer, 2009), their usage in clinical setting is problematic; protocols intended to produce differentiated cells from iPSCs have proven effective in limiting the occurrence of tumors both in mice (Liu et al., 2013; Suzuki et al., 2013) and in non-primate models that more closely resemble human physiology (Hong et al., 2014); as this line of research progresses, it will be feasible to use this technology to develop constructs from the patient's own differentiated cells, in a clinical testing framework offsetting potential benefits from limited risks (Goldring et al., 2011).

Another topic that will need to be addressed before the clinical application of SMTE constructs is also correlated to the immune reaction to the devices and to the conditions present at the site of implantation: these devices are in situ implants in recently wounded sites which do not replicate the conditions of VML encountered in clinical setting (Grogan et al., 2011; Li et al., 2013a): it is not common practice to develop animal models of VML in which the site of implantation had already undergone a normal repair process which resulted in the formation of scar tissue. As the homeostasis of the site of injury is much different compared to that of uninjured tissues, the predictive value of the animal models is diminished, and even more so when the damage is compounded by genetic mutations leading to defects in the repair process (Bosurgi et al., 2011). 
Table 2 | In vivo models of interest.

\begin{tabular}{|c|c|c|c|c|}
\hline References & Model & Scaffold & Construct type & Relevant details \\
\hline Corona et al., 2014 & Heterologous MDCs & BAM & TA VML; Lewis rats & Uniaxial mechanical strain \\
\hline Juhas et al., 2014 & $\begin{array}{l}\text { GCaMP3+ Sprague-Dawley } \\
\text { muscle tissue }\end{array}$ & Fibrin/Matrigel & $\begin{array}{l}\text { In vitro model; dorsal } \\
\text { skinfold window chamber in } \\
\text { nude mice }\end{array}$ & $\begin{array}{l}\text { Self contraction; in vitro } \\
\text { maturation; in vivo vascularization; } \\
\text { in vivo CTX damage regeneration }\end{array}$ \\
\hline Carosio et al., 2013 & Autologous muscle tissue & Autologous ECM & $\begin{array}{l}\text { EDL VML; C57BL6 WT, } \\
\text { MLC/hAP }\end{array}$ & $\begin{array}{l}\text { Self assembly, self contraction; } \\
\text { response to electrical stimuli; } \\
\text { vascularization }\end{array}$ \\
\hline Corona et al., 2013a & Autologous muscle tissue & Autologous ECM & TA VML; Lewis rats & In vivo filler \\
\hline Criswell et al., 2013 & $\begin{array}{l}\text { GFP-FVB MPCs; HUVECs; } \\
10 T 1 / 2 \text { cells }\end{array}$ & Matrigel & $\begin{array}{l}\text { Subcutaneous insertion in } \\
\text { nude mice }\end{array}$ & $\begin{array}{l}\text { In vivo activity of ECs and } \\
\text { pericytes on SMTE constructs }\end{array}$ \\
\hline Haraguchi et al., 2012 & $\begin{array}{l}\text { Rat cadiac cells; HUVECs; } \\
\text { HSMMCs }\end{array}$ & $\begin{array}{l}\text { PNIPAAm substrate; } \\
\text { fibrin, gelatin } \\
\text { substrate; self } \\
\text { produced ECM }\end{array}$ & $\begin{array}{l}\text { Subcutaneous dorsal } \\
\text { insertion, transplantation } \\
\text { onto infarcted heart in F344 } \\
\text { nude mice }\end{array}$ & $\begin{array}{l}\text { Cell sheet stacking; electrical } \\
\text { stimuli maturation; in vitro } \\
\text { vascularization }\end{array}$ \\
\hline Williams et al., 2012 & Explanted soleus muscle cells & $\begin{array}{l}\text { Autologous ECM on } \\
\text { fibrin }\end{array}$ & $\begin{array}{l}\text { Implantation along the } V L \text {, } \\
\text { near the sciatic nerve. } \\
\text { Innervation with sural nerve } \\
\text { in F344 }\end{array}$ & $\begin{array}{l}\text { Self contraction and effect of } \\
\text { innervation with host's nerve; } \\
\text { shift in myosin type }\end{array}$ \\
\hline Koffler et al., 2011 & $\begin{array}{l}\text { C2C12; HUVECs; human } \\
\text { foreskin fibroblasts }\end{array}$ & Surgisis SIS & $\begin{array}{l}\text { Full thickness abdominal } \\
\text { wall replacement in nude } \\
\text { mice }\end{array}$ & $\begin{array}{l}\text { Cocolture; variable in vitro } \\
\text { conditioning period }\end{array}$ \\
\hline Levenberg et al., 2005 & C2C12; HUVECs; mouse EFs & $\begin{array}{l}\text { PLLA-PGA porous } \\
\text { scaffold }\end{array}$ & $\begin{array}{l}\text { Dorsal midline } \\
\text { subcutaneous implantation } \\
\text { in CB17 SCID }\end{array}$ & Coculture; prevascularization \\
\hline Sicari et al., 2014 & - & SIS & ATC (3), quadriceps (2) VML & Clinical trial \\
\hline Mase et al., 2010 & - & BAM & Quadriceps femori VML & Clinical case \\
\hline
\end{tabular}

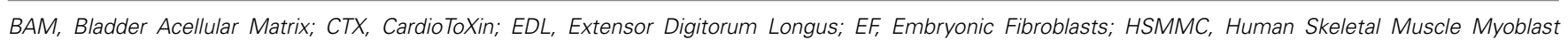

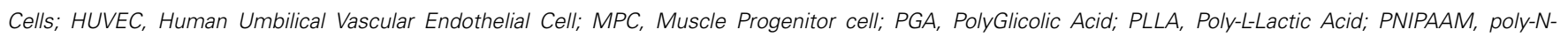
IsoPropyIAcryIAmide; SIS, Small Intestine Submucosa; TA, Tibialis Anterior.

\section{CURRENT APPROACHES}

There are numerous hurdles to be overcome before SMTE constructs will have a use in clinical settings; to the best of our knowledge, there have only been two clinical applications of regenerative medicine devices for VML in skeletal muscle, both involving in situ implantation of decellularized porcine small intestinal submucosa (SIS). In the first instance, a clinical case, a large volumetric defect in the quadriceps femori, treated 3 years before with a latissimus dorsi muscle flap (Mase et al., 2010), was treated with an acellular SIS scaffold. Following the positive outcome of this experiment a clinical trial involving five patients and a different scaffold (porcine bladder matrix) was recently published (Sicari et al., 2014), showing that the treatment did not induce an adverse effect [as xenogeneic ECM would if not completely decellularized (Keane et al., 2012)] and improvement in strength and mobility in three cases, compared to a patient-specific baseline. While this device cannot be considered the result of tissue engineering according to the usually accepted definition (Langer and Vacanti, 1993), it provides evidence that a commonly used tissue engineering scaffold can improve skeletal muscle injuries; moreover, acellular scaffolds such as SIS have shown performance comparable to decellularized muscle tissue in SMTE treating of VML (De Coppi et al., 2006; Wolf et al., 2012), which could obviate the need for human tissue as a starting material for scaffold development.

These results, and other reports analyzing the effect of empty scaffolds on cell homing (Ju et al., 2014), suggest that SMTE materials may indeed constitute a valid clinical options for the treatment of VML. A better understanding of the role of the cellular component of the devices will be required, as evidence in other engineered tissues have proven a limited structural role for the seeded cells, which are rapidly overcome and substituted by the host's own (Hibino et al., 2011). 


\section{FUTURE DIRECTIONS}

Tissue engineering and regenerative medicine treatment of skeletal muscle VML is intrinsically dependent on the dimensions of the devices meant to substitute the missing tissues: the lesions to be treated are extensive by their very own nature, and require thick flaps that are beyond what is currently possible to reproduce through TE constructs. Given the unique characteristics of skeletal muscle tissue, clinically relevant SMTE constructs will require techniques aimed at the development of functional structures of large scale in the three dimensions. The techniques that are going to see clinical application in the most immediate future are those which are derived from accepted clinical methodologies, which allow the introduction of fewer variables to be tested in the preclinical phases.

In this respect, decellularized acellular devices possess many characteristics that make them suitable for a rapid translation to a clinical application: the ECM derived from large mammals has seen ample use as grafts in vascular settings (Breymann et al., 2009), and the structure and composition of the decellularized material is capable of promoting the vascularization of the structure as it is assimilated in the body (Burdick et al., 2013; Teodori et al., 2014); nonetheless, concerns about the complete decellularization of the materials are still present, as residual traces of cellular material can lead to the failure of the device (Keane et al., 2012). An alternative to the use of heterologous material is the production of in vitro ECM from cell cultures derived from the host: this approach allows for less stringent decellularization parameters, and provide a molecular milieu closely resembling that of the original tissue, lacking however its highly organized architecture, as these devices are produced with synthetic scaffolds (Lu et al., 2011) or directly from connected cell sheets (Dahl et al., 2011). For this methodology to be applicable in VML treatment, the in vitro maturation should produce either a single construct with patent vessels (Gualandi et al., 2013) or multiple layers complete of vascular structure which would anastomose when placed in close contact. The latter approach has met with some results in recent reports (Sakaguchi et al., 2013; Sekine et al., 2013), where multiple cell sheets have been stacked to achieve multiple layer thickness to produce cellular constructs that were directly implanted in animal models. While the constructs obtained through this methodology are still far from the requirements of skeletal muscle VML treatments, they have been proven advantageous in the treatment of a case of dilated cardiomyopathy (DCM) (Sawa et al., 2012); although the dimensions of the implants $(40 \mathrm{~mm}$ of diameter and a thickness of four cell layers) were scarcely comparable to those required for VML, this case constitutes an important precedent for the application of cell sheet engineering in the treatment of striated muscle disorders.

Therefore, it is foreseeable that clinical SMTE will proceed gradually incrementing the complexity of the implanted devices, giving preference to methodologies that implement cellular populations subjected to minimal in vitro treatment, or none at all.

\section{CONCLUSIONS}

SMTE has seen a rapid development in the last decade, facilitated by the growing understanding of the processes underlying the regeneration of this tissue and the concomitant formation of vascular networks. The latter topic is of particular interest for the production of clinically relevant constructs, as the treatment of VMLs requires large, mature engineered tissues with stable vessel networks. The structure of the scaffold and mechanical stimuli applied during the in vitro phase of development have emerged as viable tools for the production of ordered, vascularized tissues with significant prospective clinical applications. As decellularized materials are undergoing clinical trials, it is foreseeable that clinical devices composed of ordered scaffolds and autologous vascular compartments will also be used in the treatment of VMLs.

\section{REFERENCES}

Aärimaa, V., Kääriäinen, M., Vaittinen, S., Tanner, J., Järvinen, T., Best, T., et al. (2004). Restoration of myofiber continuity after transection injury in the rat soleus. Neuromuscul. Disord. 14, 421-428. doi: 10.1016/j.nmd.2004.03.009

Agostini, T., Lazzeri, D., and Spinelli, G. (2013). Anterolateral thigh flap: systematic literature review of specific donor-site complications and their management. J. Craniomaxillofac. Surg. 41, 15-21. doi: 10.1016/j.jcms.2012.05.003

Ahmed, W. W., Wolfram, T., Goldyn, A. M., Bruellhoff, K., Rioja, B. A., Moller, M., et al. (2010). Myoblast morphology and organization on biochemically micropatterned hydrogel coatings under cyclic mechanical strain. Biomaterials 31, 250-258. doi: 10.1016/j.biomaterials.2009.09.047

Alekseeva, T., Unger, R., Brochhausen, C., Brown, R., and Kirkpatrick, C. (2014). Engineering a micro-vascular capillary bed in a tissue-like collagen construct. Tissue Eng. Part A. doi: 10.1089/ten.tea.2013.0570. [Epub ahead of print].

Amariglio, N., Hirshberg, A., Scheithauer, B., Cohen, Y., Loewenthal, R., Trakhtenbrot, L., et al. (2009). Donor-derived brain tumor following neural stem cell transplantation in an ataxia telangiectasia patient. PLoS Med. 6:e1000029. doi: 10.1371/journal.pmed.1000029

Araki, R., Uda, M., Hoki, Y., Sunayama, M., Nakamura, M., Ando, S., et al. (2013). Negligible immunogenicity of terminally differentiated cells derived from induced pluripotent or embryonic stem cells. Nature 494, 100-104. doi: 10.1038/nature11807

Atala, A., Bauer, S., Soker, S., Yoo, J., and Retik, A. (2006). Tissue-engineered autologous bladders for patients needing cystoplasty. Lancet 367, 1241-1246. doi: 10.1016/S0140-6736(06)68438-9

Badylak, S. F. (2014). Decellularized allogeneic and xenogeneic tissue as a bioscaffold for regenerative medicine: factors that influence the host response. Ann. Biomed. Eng. 42, 1517-1527. doi: 10.1007/s10439-013-0963-7

Bae, H., Puranik, A., Gauvin, R., Edalat, F., Carrillo-Conde, B., Peppas, N., et al. (2012). Building vascular networks. Sci. Transl. Med. 4, 160ps123. doi: 10.1126/ scitranslmed.3003688

Bareja, A., Holt, J., Luo, G., Chang, C., Lin, J., Hinken, A., et al. (2014). Human and mouse skeletal muscle stem cells: convergent and divergent mechanisms of myogenesis. PLoS ONE 9:e90398. doi: 10.1371/journal.pone.0090398

Bian, W., Juhas, M., Pfeiler, T., and Bursac, N. (2012). Local tissue geometry determines contractile force generation of engineered muscle networks. Tissue Eng. Part A 18, 957-967. doi: 10.1089/ten.tea.2011.0313

Biggs, M., Richards, R., and Dalby, M. (2010). Nanotopographical modification: a regulator of cellular function through focal adhesions. Nanomedicine 6, 619-633. doi: 10.1016/j.nano.2010.01.009

Boerckel, J., Uhrig, B., Willett, N., Huebsch, N., and Guldberg, R. (2011). Mechanical regulation of vascular growth and tissue regeneration in vivo. Proc. Natl. Acad. Sci. U.S.A. 108, 80. doi: 10.1073/pnas. 1107019108

Bohgaki, T., Atsumi, T., and Koike, T. (2007). Multiple autoimmune diseases after autologous stem-cell transplantation. N. Engl. J. Med. 357, 2734-2736. doi: 10.1056/NEJMc076383

Boldrin, L., Muntoni, F., and Morgan, J. (2010). Are human and mouse satellite cells really the same? J. Histochem. Cytochem. 58, 941-955. doi: 10.1369/jhc. 2010.956201

Boonen, K., Langelaan, M., Polak, R., van der Schaft, D., Baaijens, F., and Post, M. (2010). Effects of a combined mechanical stimulation protocol: value for skeletal muscle tissue engineering. J. Biomech. 43, 1514-1521. doi: 10.1016/j.jbiomech.2010.01.039 
Borisov, A. (1999). Regeneration of skeletal and cardiac muscle in mammals: do nonprimate models resemble human pathology? Wound Repair Regen. 7, 26-35. doi: 10.1046/j.1524-475x.1999.00026.x

Bosurgi, L., Manfredi, A., and Rovere-Querini, P. (2011). Macrophages in injured skeletal muscle: a perpetuum mobile causing and limiting fibrosis, prompting or restricting resolution and regeneration. Front. Immunol. 2:62. doi: 10.3389/fimmu.2011.00062

Breymann, T., Blanz, U., Wojtalik, M., Daenen, W., Hetzer, R., Sarris, G., et al. (2009). European Contegra multicentre study: 7-year results after 165 valved bovine jugular vein graft implantations. Thorac. Cardiovasc. Surg. 57, 257-269. doi: 10.1055/s-0029-1185513

Burdick, J., Mauck, R., Gorman, J., and Gorman, R. (2013). Acellular biomaterials: an evolving alternative to cell-based therapies. Sci. Transl. Med. 5, 176ps174. doi: 10.1126/scitranslmed.3003997

Candiani, G., Riboldi, S., Sadr, N., Lorenzoni, S., Neuenschwander, P., Montevecchi, F., et al. (2010). Cyclic mechanical stimulation favors myosin heavy chain accumulation in engineered skeletal muscle constructs. J. Appl. Biomater. Biomech. 8, 68-75. doi: 10.5301/JABB.2010.4829

Carmeliet, P., and Tessier-Lavigne, M. (2005). Common mechanisms of nerve and blood vessel wiring. Nature 436, 193-200. doi: 10.1038/nature03875

Carosio, S., Barberi, L., Rizzuto, E., Nicoletti, C., Prete, Z., and Musarò, A. (2013). Generation of eX vivo-vascularized Muscle Engineered Tissue (X-MET). Sci. Rep. 3:1420. doi: 10.1038/srep01420

Chargé, S., and Rudnicki, M. (2004). Cellular and molecular regulation of muscle regeneration. Physiol. Rev. 84, 209-238. doi: 10.1152/physrev.00019.2003

Cheng, G., Liao, S., Kit Wong, H., Lacorre, D., di Tomaso, E., Au, P., et al. (2011). Engineered blood vessel networks connect to host vasculature via wrappingand-tapping anastomosis. Blood 118, 4740-4749. doi: 10.1182/blood-2011-02338426

Chiu, L., Montgomery, M., Liang, Y., Liu, H., and Radisic, M. (2012). Perfusable branching microvessel bed for vascularization of engineered tissues. Proc. Natl. Acad. Sci. U.S.A. 109, 23. doi: 10.1073/pnas.1210580109

Christoffersson, G., Vågesjö, E., Vandooren, J., Lidén, M., Massena, S., Reinert, R., et al. (2012). VEGF-A recruits a proangiogenic MMP-9-delivering neutrophil subset that induces angiogenesis in transplanted hypoxic tissue. Blood 120, 4653-4662. doi: 10.1182/blood-2012-04-421040

Ciciliot, S., and Schiaffino, S. (2010). Regeneration of mammalian skeletal muscle. Basic mechanisms and clinical implications. Curr. Pharm. Des. 16, 906-914. doi: 10.2174/138161210790883453

Conconi, M., De Coppi, P., Bellini, S., Zara, G., Sabatti, M., Marzaro, M., et al. (2005). Homologous muscle acellular matrix seeded with autologous myoblasts as a tissue-engineering approach to abdominal wall-defect repair. Biomaterials 26, 2567-2574. doi: 10.1016/j.biomaterials.2004.07.035

Corona, B., Garg, K., Ward, C., McDaniel, J., Walters, T., and Rathbone, C. (2013a). Autologous minced muscle grafts: a tissue engineering therapy for the volumetric loss of skeletal muscle. Am. J. Physiol. Cell Physiol. 305, C761-C775. doi: 10.1152/ajpcell.00189.2013

Corona, B., Ward, C., Baker, H., Walters, T., and Christ, G. (2014). Implantation of in vitro tissue engineered muscle repair constructs and bladder acellular matrices partially restore in vivo skeletal muscle function in a rat model of volumetric muscle loss injury. Tissue Eng. Part A 20, 705-715. doi: 10.1089/ten.TEA.2012.0761

Corona, B., Wu, X., Ward, C., McDaniel, J., Rathbone, C., and Walters, T. (2013b). The promotion of a functional fibrosis in skeletal muscle with volumetric muscle loss injury following the transplantation of muscle-ECM. Biomaterials 34, 3324-3335. doi: 10.1016/j.biomaterials.2013.01.061

Criswell, T., Corona, B., Wang, Z., Zhou, Y., Niu, G., Xu, Y., et al. (2013). The role of endothelial cells in myofiber differentiation and the vascularization and innervation of bioengineered muscle tissue in vivo. Biomaterials 34, 140-149. doi: 10.1016/j.biomaterials.2012.09.045

Dahl, S., Kypson, A., Lawson, J., Blum, J., Strader, J., Li, Y., et al. (2011). Readily available tissue-engineered vascular grafts. Sci. Transl. Med. 3, 68ra69. doi: 10.1126/scitranslmed.3001426

Dalby, M., McCloy, D., Robertson, M., Agheli, H., Sutherland, D., Affrossman, S., et al. (2006). Osteoprogenitor response to semi-ordered and random nanotopographies. Biomaterials 27, 2980-2987. doi: 10.1016/j.biomaterials. 2006.01.010

De Coppi, P., Bellini, S., Conconi, M., Sabatti, M., Simonato, E., Gamba, P., et al. (2006). Myoblast-acellular skeletal muscle matrix constructs guarantee a long-term repair of experimental full-thickness abdominal wall defects. Tissue Eng. 12, 1929-1936. doi: 10.1089/ten.2006.12.1929

De Coppi, P., Delo, D., Farrugia, L., Udompanyanan, K., Yoo, J., Nomi, M., et al. (2005). Angiogenic gene-modified muscle cells for enhancement of tissue formation. Tissue Eng. 11, 1034-1044. doi: 10.1089/ten.2005.11.1034

de Jonge, N., Foolen, J., Brugmans, M., Söntjens, S., Baaijens, F., and Bouten, C. (2014). Degree of scaffold degradation influences collagen (re)orientation in engineered tissues. Tissue Eng. Part A 20, 1747-1757. doi: 10.1089/ten.TEA. 2013.0517

Dellavalle, A., Maroli, G., Covarello, D., Azzoni, E., Innocenzi, A., Perani, L., et al. (2011). Pericytes resident in postnatal skeletal muscle differentiate into muscle fibres and generate satellite cells. Nat. Commun. 2, 499. doi: $10.1038 /$ ncomms 1508

Dennis, R., and Kosnik, P. (2000). Excitability and isometric contractile properties of mammalian skeletal muscle constructs engineered in vitro. In Vitro Cell. Dev. Biol. Anim. 36, 327-335. doi: 10.1290/1071-2690(2000)036<0327:EAICPO>2. $0 . \mathrm{CO} ; 2$

Dennis, R., Kosnik, P., and Gilbert, M. (2001). Excitability and contractility of skeletal muscle engineered from primary cultures and cell lines. Am. J. Physiol. Cell Physiol. 280, C288-C295.

Discher, D., Janmey, P., and Wang, Y.-L. (2005). Tissue cells feel and respond to the stiffness of their substrate. Science 310, 1139-1143. doi: $10.1126 /$ science. 1116995

Egusa, H., Kobayashi, M., Matsumoto, T., Sasaki, J.-I., Uraguchi, S., and Yatani, H. (2013). Application of cyclic strain for accelerated skeletal myogenic differentiation of mouse bone marrow-derived mesenchymal stromal cells with cell alignment. Tissue Eng. Part A 19, 770-782. doi: 10.1089/ten.tea. 2012.0164

Elmer, D. F. K., Amrinder, S. N., Lee, E. W., Ji, W., Joseph, S., Cristina, H. A., et al. (2011). Bioprinting of growth factors onto aligned sub-micron fibrous scaffolds for simultaneous control of cell differentiation and alignment. Biomaterials 32 8097-8107. doi: 10.1016/j.biomaterials.2011.07.025

Engler, A., Griffin, M., Sen, S., Bönnemann, C., Sweeney, H., and Discher, D. (2004). Myotubes differentiate optimally on substrates with tissue-like stiffness: pathological implications for soft or stiff microenvironments. J. Cell Biol. 166, 877-887. doi: 10.1083/jcb.200405004

Engler, A., Sen, S., Sweeney, H., and Discher, D. (2006). Matrix elasticity directs stem cell lineage specification. Cell 126, 677-689. doi: 10.1016/j.cell.2006. 06.044

Eyckmans, J., Boudou, T., Yu, X., and Chen, C. (2011). A hitchhiker's guide to mechanobiology. Dev. Cell 21, 35-47. doi: 10.1016/j.devcel.2011.06.015

Feaver, R., Gelfand, B., and Blackman, B. (2013). Human haemodynamic frequency harmonics regulate the inflammatory phenotype of vascular endothelial cells. Nat. Commun. 4, 1525. doi: 10.1038/ncomms 2530

Fisher, M., and Mauck, R. (2013). Tissue engineering and regenerative medicine: recent innovations and the transition to translation. Tissue Eng. Part B Rev. 19, 1-13. doi: 10.1089/ten.teb.2012.0723

Fuoco, C., Sangalli, E., Vono, R., Testa, S., Sacchetti, B., Latronico, M. V. G., et al. (2014). 3D hydrogel environment rejuvenates aged pericytes for skeletal muscle tissue engineering. Front. Physiol. 5:203. doi: 10.3389/fphys.2014.00203

Garland, C., and Pomerantz, J. (2012). Regenerative strategies for craniofacial disorders. Front. Physiol. 3:453. doi: 10.3389/fphys.2012.00453

Gayraud-Morel, B., Chrétien, F., and Tajbakhsh, S. (2009). Skeletal muscle as a paradigm for regenerative biology and medicine. Regen. Med. 4, 293-319. doi: 10.2217/17460751.4.2.293

Gianni-Barrera, R., Trani, M., Fontanellaz, C., Heberer, M., Djonov, V., Hlushchuk, R., et al. (2013). VEGF over-expression in skeletal muscle induces angiogenesis by intussusception rather than sprouting. Angiogenesis 16, 123-136. doi: 10.1007/s10456-012-9304-y

Goldring, C. E., Duffy, P. A., Benvenisty, N., Andrews, P. W., Ben-David, U., Eakins, R., et al. (2011). Assessing the safety of stem cell therapeutics. Cell Stem Cell 8, 618-628. doi: 10.1016/j.stem.2011.05.012

Griffith, C., Miller, C., Sainson, R., Calvert, J., Jeon, N., Hughes, C., et al. (2005) Diffusion limits of an in vitro thick prevascularized tissue. Tissue Eng. 11, 257-266. doi: 10.1089/ten.2005.11.257

Grogan, B., Hsu, J., and Skeletal Trauma Research, C. (2011). Volumetric muscle loss. J. Am. Acad. Orthop. Surg. 19(Suppl. 1), 7.

Gualandi, C., Zucchelli, A., Fernández Osorio, M., Belcari, J., and Focarete, M. (2013). Nanovascularization of polymer matrix: generation of nanochannels 
and nanotubes by sacrificial electrospun fibers. Nano Lett. 13, 5385-5390. doi: $10.1021 / \mathrm{nl} 402930 \mathrm{x}$

Guilak, F., Butler, D., Goldstein, S., and Baaijens, F. (2014). Biomechanics and mechanobiology in functional tissue engineering. J. Biomech. 47, 1933-1940. doi: 10.1016/j.jbiomech.2014.04.019

Gurtner, G., Werner, S., Barrandon, Y., and Longaker, M. (2008). Wound repair and regeneration. Nature 453, 314-321. doi: 10.1038/nature07039

Hanjaya-Putra, D., Shen, Y.-I., Wilson, A., Fox-Talbot, K., Khetan, S., Burdick, J., et al. (2013). Integration and regression of implanted engineered human vascular networks during deep wound healing. Stem Cells Transl. Med. 2, 297-306. doi: 10.5966/sctm.2012-0111

Haraguchi, Y., Shimizu, T., Sasagawa, T., Sekine, H., Sakaguchi, K., Kikuchi, T., et al. (2012). Fabrication of functional three-dimensional tissues by stacking cell sheets in vitro. Nat. Protoc. 7, 850-858. doi: 10.1038/nprot.2012.027

Heredia, J., Mukundan, L., Chen, F., Mueller, A., Deo, R., Locksley, R., et al. (2013). Type 2 innate signals stimulate fibro/adipogenic progenitors to facilitate muscle regeneration. Cell 153, 376-388. doi: 10.1016/j.cell.2013.02.053

Hibino, N., Villalona, G., Pietris, N., Duncan, D. R., Schoffner, A., Roh, J. D., et al. (2011). Tissue-engineered vascular grafts form neovessels that arise from regeneration of the adjacent blood vessel. FASEB J. 25, 2731-2739. doi: 10.1096/fj.11-182246

Hong, S. G., Winkler, T., Wu, C., Guo, V., Pittaluga, S., Nicolae, A., et al. (2014). Path to the clinic: assessment of iPSC-based cell therapies in vivo in a nonhuman primate model. Cell Rep. 7, 1298-1309. doi: 10.1016/j.celrep.2014.04.019

Hooper, R., Hernandez, K., Boyko, T., Harper, A., Joyce, J., Golas, A., et al. (2014). Fabrication and in vivo microanastomosis of vascularized tissue-engineered constructs. Tissue Eng. Part A. doi: 10.1089/ten.tea.2013.0583. [Epub ahead of print].

Hosseini, V., Ahadian, S., Ostrovidov, S., Camci-Unal, G., Chen, S., Kaji, H., et al. (2012). Engineered contractile skeletal muscle tissue on a microgrooved methacrylated gelatin substrate. Tissue Eng. Part A 18, 2453-2465. doi: 10.1089/ten.tea.2012.0181

Huxley, H., and Hanson, J. (1954). Changes in the cross-striations of muscle during contraction and stretch and their structural interpretation. Nature 173, 973-976. doi: 10.1038/173973a0

Järvinen, T., Järvinen, M., and Kalimo, H. (2013). Regeneration of injured skeletal muscle after the injury. Muscles Ligaments Tendons J. 3, 337-345. doi: 10.11138/ mltj/2013.3.4.337

Joe, A., Yi, L., Natarajan, A., Le Grand, F., So, L., Wang, J., et al. (2010). Muscle injury activates resident fibro/adipogenic progenitors that facilitate myogenesis. Nat. Cell Biol. 12, 153-163. doi: 10.1038/ncb2015

Ju, Y. M., Atala, A., Yoo, J. J., and Lee, S. J. (2014). In situ regeneration of skeletal muscle tissue through host cell recruitment. Acta Biomater. 10, 4332-4339. doi: 10.1016/j.actbio.2014.06.022

Juhas, M., Engelmayr, G. C., Fontanella, A. N., Palmer, G. M., and Bursac, N. (2014). Biomimetic engineered muscle with capacity for vascular integration and functional maturation in vivo. Proc. Natl. Acad. Sci. U.S.A. 111, 5508-5513. doi: 10.1073/pnas.1402723111

Kang, K.-T., Allen, P., and Bischoff, J. (2011). Bioengineered human vascular networks transplanted into secondary mice reconnect with the host vasculature and re-establish perfusion. Blood 118, 6718-6721. doi: 10.1182/blood-2011-08375188

Karande, T., Ong, J., and Agrawal, C. (2004). Diffusion in musculoskeletal tissue engineering scaffolds: design issues related to porosity, permeability, architecture, and nutrient mixing. Ann. Biomed. Eng. 32, 1728-1743. doi: 10.1007/s10439-004-7825-2

Keane, T., Londono, R., Turner, N., and Badylak, S. (2012). Consequences of ineffective decellularization of biologic scaffolds on the host response. Biomaterials 33, 1771-1781. doi: 10.1016/j.biomaterials.2011.10.054

Kelc, R., Trapecar, M., Vogrin, M., and Cencic, A. (2013). Skeletal muscle-derived cell cultures as potent models in regenerative medicine research. Muscle Nerve 47, 477-482. doi: 10.1002/mus.23688

Kelly, R. (2010). Core issues in craniofacial myogenesis. Exp. Cell Res. 316, 3034-3041. doi: 10.1016/j.yexcr.2010.04.029

Kilarski, W., Samolov, B., Petersson, L., Kvanta, A., and Gerwins, P. (2009). Biomechanical regulation of blood vessel growth during tissue vascularization. Nat. Med. 15, 657-664. doi: 10.1038/nm.1985

Knoeplfer, P. S. (2009). Deconstructing stem cell tumorigenicity: a roadmap to safe regenerative medicine. Stem Cells 27, 1050-1056. doi: 10.1002/stem.37
Koffler, J., Kaufman-Francis, K., Shandalov, Y., Yulia, S., Egozi, D., Dana, E., et al. (2011). Improved vascular organization enhances functional integration of engineered skeletal muscle grafts. Proc. Natl. Acad. Sci. U.S.A. 108, 14789-14794. doi: 10.1073/pnas.1017825108

Kolesky, D., Truby, R., Gladman, A., Busbee, T., Homan, K., and Lewis, J. (2014). 3D bioprinting of vascularized, heterogeneous cell-laden tissue constructs. $A d v$. Mater. 26, 3124-3130. doi: 10.1002/adma.201305506

Koopman, R., Ly, C. H., and Ryall, J. G. (2014). A metabolic link to skeletal muscle wasting and regeneration. Front. Physiol. 5:32. doi: 10.3389/fphys.2014.00032

Lam, M., Huang, Y.-C., Birla, R., and Takayama, S. (2009). Microfeature guided skeletal muscle tissue engineering for highly organized 3dimensional free-standing constructs. Biomaterials 30, 1150-1155. doi: 10.1016/j.biomaterials.2008.11.014

Langer, R., and Vacanti, J. (1993). Tissue engineering. Science 260, 920-926. doi: 10.1126/science. 8493529

Lemos, D., Paylor, B., Chang, C., Sampaio, A., Underhill, T., and Rossi, F. (2012). Functionally convergent white adipogenic progenitors of different lineages participate in a diffused system supporting tissue regeneration. Stem Cells 30, 1152-1162. doi: 10.1002/stem.1082

Leong, M., Toh, J., Du, C., Narayanan, K., Lu, H., Lim, T., et al. (2013). Patterned prevascularised tissue constructs by assembly of polyelectrolyte hydrogel fibres. Nat. Commun. 4, 2353. doi: 10.1038/ncomms3353

Lesman, A., Gepstein, L., and Levenberg, S. (2010). Vascularization shaping the heart. Ann. N.Y. Acad. Sci. 1188, 46-51. doi: 10.1111/j.1749-6632.2009.05082.x

Lesman, A., Koffler, J., Atlas, R., Blinder, Y. J., Kam, Z., and Levenberg, S. (2011). Engineering vessel-like networks within multicellular fibrin-based constructs. Biomaterials 32, 7856-7869. doi: 10.1016/j.biomaterials.2011.07.003

Levenberg, S., Rouwkema, J., Macdonald, M., Garfein, E. S., Kohane, D. S., Darland, D. C., et al. (2005). Engineering vascularized skeletal muscle tissue. Nat. Biotechnol. 23, 879-884. doi: 10.1038/nbt1109

Li, M., Dickinson, C., Finkelstein, E., Neville, C., and Sundback, C. (2011). The role of fibroblasts in self-assembled skeletal muscle. Tissue Eng. Part A 17, 2641-2650. doi: 10.1089/ten.tea.2010.0700

Li, M., Willett, N., Uhrig, B., Guldberg, R., and Warren, G. (2013a). Functional analysis of limb recovery following autograft treatment of volumetric muscle loss in the quadriceps femoris. J. Biomech. 47, 2013-2021. doi: 10.1016/j. jbiomech.2013.10.057

Li, Y., Huang, G., Zhang, X., Wang, L., Du, Y., Lu, T., et al. (2013b). Engineering cell alignment in vitro. Biotechnol. Adv. 32, 347-365. doi: 10.1016/j.biotechadv. 2013.11.007

Lieber, R., and Fridén, J. (2000). Functional and clinical significance of skeletal muscle architecture. Muscle Nerve 23, 1647-1666. doi: 10.1002/10974598(200011)23:11<1647::AID-MUS1>3.0.co;2-M

Liu, G., Mac Gabhann, F., and Popel, A. (2012). Effects of fiber type and size on the heterogeneity of oxygen distribution in exercising skeletal muscle. PLoS ONE 7:e44375. doi: 10.1371/journal.pone.0044375

Liu, Z., Tang, Y., Lü, S., Zhou, J., Du, Z., Duan, C., et al. (2013). The tumourigenicity of iPS cells and their differentiated derivates. J. Cell. Mol. Med. 17, 782-791. doi: $10.1111 / \mathrm{jcmm} .12062$

Livne, A., Bouchbinder, E., and Geiger, B. (2014). Cell reorientation under cyclic stretching. Nat. Commun. 5:3938. doi: 10.1038/ncomms4938

Lu, H., Hoshiba, T., Kawazoe, N., and Chen, G. (2011). Autologous extracellular matrix scaffolds for tissue engineering. Biomaterials 32, 2489-2499. doi: 10.1016/j.biomaterials.2010.12.016

Macchiarini, P., Jungebluth, P., Go, T., Asnaghi, M., Rees, L., Cogan, T., et al. (2008). Clinical transplantation of a tissue-engineered airway. Lancet 372, 2023-2030. doi: 10.1016/S0140-6736(08)61598-6

Mantovani, A., Biswas, S., Galdiero, M., Sica, A., and Locati, M. (2013). Macrophage plasticity and polarization in tissue repair and remodelling. J. Pathol. 229, 176-185. doi: 10.1002/path.4133

Martin, I., Simmons, P. J., and Williams, D. F. (2014). Manufacturing challenges in regenerative medicine. Sci. Transl. Med. 6, 232fs216. doi: 10.1126/scitranslmed. 3008558

Mase, V., Hsu, J., Wolf, S., Wenke, J., Baer, D., Owens, J., et al. (2010). Clinical application of an acellular biologic scaffold for surgical repair of a large, traumatic quadriceps femoris muscle defect. Orthopedics 33, 511. doi: 10.3928/0147744720100526-24

Mauro, A. (1961). Satellite cell of skeletal muscle fibers. J. Biophys. Biochem. Cytol. 9, 493-495. doi: 10.1083/jcb.9.2.493 
McAllister, T., Maruszewski, M., Garrido, S., Wystrychowski, W., Dusserre, N., Marini, A., et al. (2009). Effectiveness of haemodialysis access with an autologous tissue-engineered vascular graft: a multicentre cohort study. Lancet 373, 1440-1446. doi: 10.1016/S0140-6736(09)60248-8

Mei, Y., Saha, K., Bogatyrev, S. R., Yang, J., Hook, A. L., Kalcioglu, Z. I., et al. (2010). Combinatorial development of biomaterials for clonal growth of human pluripotent stem cells. Nat. Mater. 9, 768-778. doi: 10.1038/nmat2812

Mertens, J., Sugg, K., Lee, J., and Larkin, L. (2014). Engineering muscle constructs for the creation of functional engineered musculoskeletal tissue. Regen. Med. 9, 89-100. doi: 10.2217/rme.13.81

Miller, J., Stevens, K., Yang, M., Baker, B., Nguyen, D.-H. T., Cohen, D., et al. (2012). Rapid casting of patterned vascular networks for perfusable engineered threedimensional tissues. Nat. Mater. 11, 768-774. doi: 10.1038/nmat3357

Monge, C., Ren, K., Berton, K., Guillot, R., Peyrade, D., and Picart, C. (2012). Engineering muscle tissues on microstructured polyelectrolyte multilayer films. Tissue Eng. Part A 18, 1664-1676. doi: 10.1089/ten.tea.2012.0079

Morimoto, Y., Kato-Negishi, M., Onoe, H., and Takeuchi, S. (2013). Threedimensional neuron-muscle constructs with neuromuscular junctions. Biomaterials 34, 9413-9419. doi: 10.1016/j.biomaterials.2013.08.062

Mozzetta, C., Consalvi, S., Saccone, V., Tierney, M., Diamantini, A., Mitchell, K., et al. (2013). Fibroadipogenic progenitors mediate the ability of HDAC inhibitors to promote regeneration in dystrophic muscles of young, but not old Mdx mice. EMBO Mol. Med. 5, 626-639. doi: 10.1002/emmm.201202096

Mujagic, E., Gianni-Barrera, R., Trani, M., Patel, A., Gürke, L., Heberer, M., et al. (2013). Induction of aberrant vascular growth, but not of normal angiogenesis, by cell-based expression of different doses of human and mouse VEGF is species-dependent. Hum. Gene Ther. Methods 24, 28-37. doi: 10.1089/hgtb. 2012.197

Muraoka, M., Shimizu, T., Itoga, K., Takahashi, H., and Okano, T. (2013). Control of the formation of vascular networks in $3 \mathrm{D}$ tissue engineered constructs. Biomaterials 34, 696-703. doi: 10.1016/j.biomaterials.2012.10.009

Murphy, M., Lawson, J., Mathew, S., Hutcheson, D., and Kardon, G. (2011). Satellite cells, connective tissue fibroblasts and their interactions are crucial for muscle regeneration. Development 138, 3625-3637. doi: 10.1242/dev.064162

Nagamori, E., Ngo, T., Takezawa, Y., Saito, A., Sawa, Y., Shimizu, T., et al. (2013). Network formation through active migration of human vascular endothelial cells in a multilayered skeletal myoblast sheet. Biomaterials 34, 662-668. doi: 10.1016/j.biomaterials.2012.08.055

Naito, Y., Imai, Y., Shin'oka, T., Kashiwagi, J., Aoki, M., Watanabe, M., et al. (2003). Successful clinical application of tissue-engineered graft for extracardiac Fontan operation. J. Thorac. Cardiovasc. Surg. 125, 419-420. doi: 10.1067/mtc. 2003.134

Nava, M., Raimondi, M., and Pietrabissa, R. (2014). Bio-chemo-mechanical models for nuclear deformation in adherent eukaryotic cells. Biomech. Model. Mechanobiol. 13, 929-943. doi: 10.1007/s10237-014-0558-8

Nunes, S., Miklas, J., Liu, J., Aschar-Sobbi, R., Xiao, Y., Zhang, B., et al. (2013). Biowire: a platform for maturation of human pluripotent stem cell-derived cardiomyocytes. Nat. Methods 10, 781-787. doi: 10.1038/nmeth.2524

Ostrovidov, S., Hosseini, V., Ahadian, S., Fujie, T., Parthiban, S. P., Bae, H., et al. (2014). Skeletal muscle tissue engineering: methods to form skeletal myotubes and their applications. Tissue Eng. Part B Rev. doi: 10.1089/ten.teb.2013.0534. [Epub ahead of print].

Ott, H., Matthiesen, T., Goh, S.-K., Black, L., Kren, S., Netoff, T., et al. (2008). Perfusion-decellularized matrix: using nature's platform to engineer a bioartificial heart. Nat. Med. 14, 213-221. doi: 10.1038/nm1684

Palamà, I., D’Amone, S., Coluccia, A., and Gigli, G. (2013). Micropatterned polyelectrolyte nanofilms promote alignment and myogenic differentiation of C2C12 cells in standard growth media. Biotechnol. Bioeng. 110, 586-596. doi: 10.1002/bit.24626

Pannérec, A., Marazzi, G., and Sassoon, D. (2012). Stem cells in the hood: the skeletal muscle niche. Trends Mol. Med. 18, 599-606. doi: 10.1016/j.molmed.2012. 07.004

Pashuck, E., and Stevens, M. (2012). Designing regenerative biomaterial therapies for the clinic. Sci. Transl. Med. 4, 160sr164. doi: 10.1126/scitranslmed.3002717

Pennisi, C., Olesen, C., de Zee, M., Rasmussen, J., and Zachar, V. (2011). Uniaxial cyclic strain drives assembly and differentiation of skeletal myocytes. Tissue Eng. Part A 17, 2543-2550. doi: 10.1089/ten.tea.2011.0089

Radisic, M., Malda, J., Epping, E., Geng, W., Langer, R., and Vunjak-Novakovic, G. (2006). Oxygen gradients correlate with cell density and cell viability in engineered cardiac tissue. Biotechnol. Bioeng. 93, 332-343. doi: 10.1002/bit. 20722

Radisic, M., Yang, L., Boublik, J., Cohen, R., Langer, R., Freed, L., et al. (2004). Medium perfusion enables engineering of compact and contractile cardiac tissue. Am. J. Physiol. Heart Circ. Physiol. 286, 16. doi: 10.1152/ajpheart. 00171.2003

Raghavan, S., Nelson, C., Baranski, J., Lim, E., and Chen, C. (2010). Geometrically controlled endothelial tubulogenesis in micropatterned gels. Tissue Eng. Part A 16, 2255-2263. doi: 10.1089/ten.tea.2009.0584

Ranga, A., Gobaa, S., Okawa, Y., Mosiewicz, K., Negro, A., and Lutolf, M. P. (2014) 3D niche microarrays for systems-level analyses of cell fate. Nat. Commun. 5:4324. doi: 10.1038/ncomms5324

Riboldi, S., Sadr, N., Pigini, L., Neuenschwander, P., Simonet, M., Mognol, P., et al. (2008). Skeletal myogenesis on highly orientated microfibrous polyesterurethane scaffolds. J. Biomed. Mater. Res. Part A 84, 1094-1101. doi: 10.1002/jbm.a.31534

Roh, J., Sawh-Martinez, R., Brennan, M., Jay, S., Devine, L., Rao, D., et al. (2010). Tissue-engineered vascular grafts transform into mature blood vessels via an inflammation-mediated process of vascular remodeling. Proc. Natl. Acad. Sci. U.S.A. 107, 4669-4674. doi: 10.1073/pnas.0911465107

Rouwkema, J., Gibbs, S., Lutolf, M., Martin, I., Vunjak-Novakovic, G., and Malda, J. (2011). In vitro platforms for tissue engineering: implications for basic research and clinical translation. J. Tissue Eng. Regen. Med. 5, 7. doi: 10.1002/term.414

Saccone, V., Consalvi, S., Giordani, L., Mozzetta, C., Barozzi, I., Sandoná, M., et al. (2014). HDAC-regulated myomiRs control BAF60 variant exchange and direct the functional phenotype of fibro-adipogenic progenitors in dystrophic muscles. Genes Dev. 28, 841-857. doi: 10.1101/gad.234468.113

Saclier, M., Cuvellier, S., Magnan, M., Mounier, R., and Chazaud, B. (2013). Monocyte/macrophage interactions with myogenic precursor cells during skeletal muscle regeneration. FEBS J. 280, 4118-4130. doi: 10.1111/febs.12166

Sadr, N., Pippenger, B. E., Scherberich, A., Wendt, D., Mantero, S., Martin, I., et al. (2012). Enhancing the biological performance of synthetic polymeric materials by decoration with engineered, decellularized extracellular matrix. Biomaterials 33, 5085-5093. doi: 10.1016/j.biomaterials.2012.03.082

Sakaguchi, K., Shimizu, T., Horaguchi, S., Sekine, H., Yamato, M., Umezu, M., et al. (2013). In vitro engineering of vascularized tissue surrogates. Sci. Rep. 3:1316. doi: 10.1038/srep01316

Sala, A., Hänseler, P., Ranga, A., Lutolf, M. P., Vörös, J., Ehrbar, M., et al. (2011). Engineering 3D cell instructive microenvironments by rational assembly of artificial extracellular matrices and cell patterning. Integr. Biol. (Camb) 3, 1102-1111. doi: 10.1039/clib00045d

Salimath, A. S., and García, A. J. (2014). Biofunctional hydrogels for skeletal muscle constructs. J. Tissue Eng. Regen. Med. doi: 10.1002/term.1881. [Epub ahead of print].

Sawa, Y., Miyagawa, S., Sakaguchi, T., Fujita, T., Matsuyama, A., Saito, A., et al. (2012). Tissue engineered myoblast sheets improved cardiac function sufficiently to discontinue LVAS in a patient with DCM: report of a case. Surg. Today 42, 181-184. doi: 10.1007/s00595-011-0106-4

Schmalbruch, H. (1976). The morphology of regeneration of skeletal muscles in the rat. Tissue Cell 8, 673-692. doi: 10.1016/0040-8166(76)90039-2

Sekine, H., Shimizu, T., Sakaguchi, K., Dobashi, I., Wada, M., Yamato, M., et al. (2013). In vitro fabrication of functional three-dimensional tissues with perfusable blood vessels. Nat. Commun. 4, 1399. doi: 10.1038/ ncomms 2406

Seok, J., Warren, H., Cuenca, A., Mindrinos, M., Baker, H., Xu, W., et al. (2013). Genomic responses in mouse models poorly mimic human inflammatory diseases. Proc. Natl. Acad. Sci. U.S.A. 110, 3507-3512. doi: 10.1073/pnas.1222 878110

Shah, R., Knowles, J., Hunt, N., and Lewis, M. (2013). Development of a novel smart scaffold for human skeletal muscle regeneration. J. Tissue Eng. Regen. Med. doi: 10.1002/term.1780. [Epub ahead of print].

Shandalov, Y., Egozi, D., Koffler, J., Dado-Rosenfeld, D., Ben-Shimol, D. Freiman, A., et al. (2014). An engineered muscle flap for reconstruction of large soft tissue defects. Proc. Natl. Acad. Sci. U.S.A. 111, 6010-6015. doi: $10.1073 /$ pnas. 1402679111

Sharples, A., Player, D., Martin, N., Mudera, V., Stewart, C., and Lewis, M. (2012). Modelling in vivo skeletal muscle ageing in vitro using three-dimensional bioengineered constructs. Aging cell 11, 986-995. doi: 10.1111/j.14749726.2012.00869.x 
Shevchenko, E., Makarevich, P., Tsokolaeva, Z., Boldyreva, M., Sysoeva, V., Tkachuk, V., et al. (2013). Transplantation of modified human adipose derived stromal cells expressing VEGF165 results in more efficient angiogenic response in ischemic skeletal muscle. J. Transl. Med. 11:138. doi: 10.1186/1479-587611-138

Sicari, B. M., Rubin, J. P., Dearth, C. L., Wolf, M. T., Ambrosio, F., Boninger, M., et al. (2014). An acellular biologic scaffold promotes skeletal muscle formation in mice and humans with volumetric muscle loss. Sci. Transl. Med. 6, $234 \mathrm{ra} 258$. doi: 10.1126/scitranslmed.3008085

Snyman, C., Goetsch, K., Myburgh, K., and Niesler, C. (2013). Simple silicone chamber system for in vitro three-dimensional skeletal muscle tissue formation. Front. Physiol. 4:349. doi: 10.3389/fphys.2013.00349

Suzuki, N., Yamazaki, S., Yamaguchi, T., Okabe, M., Masaki, H., Takaki, S., et al. (2013). Generation of engraftable hematopoietic stem cells from induced pluripotent stem cells by way of teratoma formation. Mol. Ther. 21, 1424-1431. doi: $10.1038 / \mathrm{mt} .2013 .71$

Takahashi, K., and Yamanaka, S. (2006). Induction of pluripotent stem cells from mouse embryonic and adult fibroblast cultures by defined factors. Cell 126, 663-676. doi: 10.1016/j.cell.2006.07.024

Takaza, M., Moerman, K., Gindre, J., Lyons, G., and Simms, C. (2013). The anisotropic mechanical behaviour of passive skeletal muscle tissue subjected to large tensile strain. J. Mech. Behav. Biomed. Mater. 17, 209-220. doi: 10.1016/j.jmbbm.2012.09.001

Tamaki, T., Soeda, S., Hashimoto, H., Saito, K., Sakai, A., Nakajima, N., et al. (2013). 3D reconstitution of nerve-blood vessel networks using skeletal musclederived multipotent stem cell sheet pellets. Regen. Med. 8, 437-451. doi: $10.2217 / \mathrm{rme} .13 .30$

Tedesco, F., and Cossu, G. (2012). Stem cell therapies for muscle disorders. Curr. Opin. Neurol. 25, 597-603. doi: 10.1097/WCO.0b013e328357f288

Tedesco, F., Dellavalle, A., Diaz-Manera, J., Messina, G., and Cossu, G. (2010). Repairing skeletal muscle: regenerative potential of skeletal muscle stem cells. J. Clin. Invest. 120, 11-19. doi: 10.1172/JCI40373

Teixeira, C., Zamunér, S., Zuliani, J., Fernandes, C., Cruz-Hofling, M., Fernandes, I., et al. (2003). Neutrophils do not contribute to local tissue damage, but play a key role in skeletal muscle regeneration, in mice injected with Bothrops asper snake venom. Muscle Nerve 28, 449-459. doi: 10.1002/mus. 10453

Ten Broek, R., Grefte, S., and Von den Hoff, J. (2010). Regulatory factors and cell populations involved in skeletal muscle regeneration. J. Cell. Physiol. 224, 7-16. doi: $10.1002 /$ jcp. 22127

Teodori, L., Costa, A., Marzio, R., Perniconi, B., Coletti, D., Adamo, S., et al. (2014). Native extracellular matrix: a new scaffolding platform for repair of damaged muscle. Front. Physiol. 5:218. doi: 10.3389/fphys.2014.00218

Thirabanjasak, D., Tantiwongse, K., and Thorner, P. S. (2010). Angiomyeloproliferative lesions following autologous stem cell therapy. J. Am. Soc. Nephrol. 21, 1218-1222. doi: 10.1681/ASN.2009111156

Tidball, J., Dorshkind, K., and Wehling-Henricks, M. (2014). Shared signaling systems in myeloid cell-mediated muscle regeneration. Development 141, 1184-1196. doi: 10.1242/dev.098285

Tidball, J., and Villalta, S. (2010). Regulatory interactions between muscle and the immune system during muscle regeneration. Am. J. Physiol. Regul. Integr. Comp. Physiol. 298, 87. doi: 10.1152/ajpregu.00735.2009

Tirziu, D., and Simons, M. (2009). Endothelium as master regulator of organ development and growth. Vascul. Pharmacol. 50, 1-7. doi: 10.1016/j.vph.2008. 08.003

Turner, N., and Badylak, S. (2012). Regeneration of skeletal muscle. Cell Tissue Res. 347, 759-774. doi: 10.1007/s00441-011-1185-7

Turner, N. J., Badylak, J. S., Weber, D. J., and Badylak, S. F. (2012). Biologic scaffold remodeling in a dog model of complex musculoskeletal injury. J. Surg. Res. 176, 490-502. doi: 10.1016/j.jss.2011.11.1029

Uezumi, A., Ito, T., Morikawa, D., Shimizu, N., Yoneda, T., Segawa, M., et al. (2011). Fibrosis and adipogenesis originate from a common mesenchymal progenitor in skeletal muscle. J. Cell Sci. 124, 3654-3664. doi: 10.1242/jcs.086629
Unadkat, H., Hulsman, M., Cornelissen, K., Papenburg, B., Truckenmüller, R., Carpenter, A., et al. (2011). An algorithm-based topographical biomaterials library to instruct cell fate. Proc. Natl. Acad. Sci. U.S.A. 108, 16565-16570. doi: 10.1073/pnas.1109861108

van der Schaft, D., van Spreeuwel, A. C., van Assen, H., and Baaijens, F. (2011). Mechanoregulation of vascularization in aligned tissue-engineered muscle: a role for vascular endothelial growth factor. Tissue Eng. Part A 17, 2857-2865. doi: $10.1089 /$ ten.tea.2011.0214

Vandenburgh, H. (2010). High-content drug screening with engineered musculoskeletal tissues. Tissue Eng. Part B Rev. 16, 55-64. doi: 10.1089/ten.teb.2009.0445

Vandenburgh, H., Karlisch, P., and Farr, L. (1988). Maintenance of highly contractile tissue-cultured avian skeletal myotubes in collagen gel. In Vitro Cell. Dev. Biol. 24, 166-174. doi: 10.1007/BF02623542

Vandenburgh, H., Shansky, J., Del Tatto, M., and Chromiak, J. (1999). Organogenesis of skeletal muscle in tissue culture. Methods Mol. Med. 18, 217-225.

Vandenburgh, H. H., Swasdison, S., and Karlisch, P. (1991). Computer-aided mechanogenesis of skeletal muscle organs from single cells in vitro. FASEB J. 5, 2860-2867.

Wang, L., Shansky, J., and Vandenburgh, H. (2013). Induced formation and maturation of acetylcholine receptor clusters in a defined 3D bio-artificial muscle. Mol. Neurobiol. 48, 397-403. doi: 10.1007/s12035-013-8412-z

Wang, N., Tytell, J., and Ingber, D. (2009). Mechanotransduction at a distance: mechanically coupling the extracellular matrix with the nucleus. Nat. Rev. Mol. Cell Biol. 10, 75-82. doi: 10.1038/nrm2594

Wang, Y., and Rudnicki, M. (2012). Satellite cells, the engines of muscle repair. Nat. Rev. Mol. Cell Biol. 13, 127-133. doi: 10.1038/nrm3265

Weist, M., Wellington, M., Bermudez, J., Kostrominova, T., Mendias, C., Arruda, E., et al. (2012). TGF- $\beta 1$ enhances contractility in engineered skeletal muscle. J. Tissue Eng. Regen. Med. 7, 562-571. doi: 10.1002/term.551

Williams, M., Kostrominova, T., Arruda, E., and Larkin, L. (2012). Effect of implantation on engineered skeletal muscle constructs. J. Tissue Eng. Regen. Med. 7, 434-442. doi: 10.1002/term.537

Wolf, M., Daly, K., Reing, J., and Badylak, S. (2012). Biologic scaffold composed of skeletal muscle extracellular matrix. Biomaterials 33, 2916-2925. doi: 10.1016/j.biomaterials.2011.12.055

Yamato, M., Akiyama, Y., Kobayashi, J., Yang, J., Kikuchi, A., and Okano, T. (2007). Temperature-responsive cell culture surfaces for regenerative medicine with cell sheet engineering. Prog. Polym. Sci. 32, 1123-1133. doi: 10.1016/j.progpolymsci. 2007.06.002

Zhang, H., Zhou, L., and Zhang, W. (2014). Control of scaffold degradation in tissue engineering: a review. Tissue Eng. Part B Rev. doi: 10.1089/ten.teb.2013. 0452. [Epub ahead of print].

Conflict of Interest Statement: The authors declare that the research was conducted in the absence of any commercial or financial relationships that could be construed as a potential conflict of interest.

Received: 20 July 2014; accepted: 03 September 2014; published online: 22 September 2014.

Citation: Cittadella Vigodarzere G and Mantero S (2014) Skeletal muscle tissue engineering: strategies for volumetric constructs. Front. Physiol. 5:362. doi: 10.3389/fphys. 2014.00362

This article was submitted to Striated Muscle Physiology, a section of the journal Frontiers in Physiology.

Copyright (C) 2014 Cittadella Vigodarzere and Mantero. This is an open-access article distributed under the terms of the Creative Commons Attribution License (CC BY). The use, distribution or reproduction in other forums is permitted, provided the original author(s) or licensor are credited and that the original publication in this journal is cited, in accordance with accepted academic practice. No use, distribution or reproduction is permitted which does not comply with these terms. 